ilorth Carolina - Agric dep of.

Regulations for the control of contagious diseases of livestock. 1899 . 

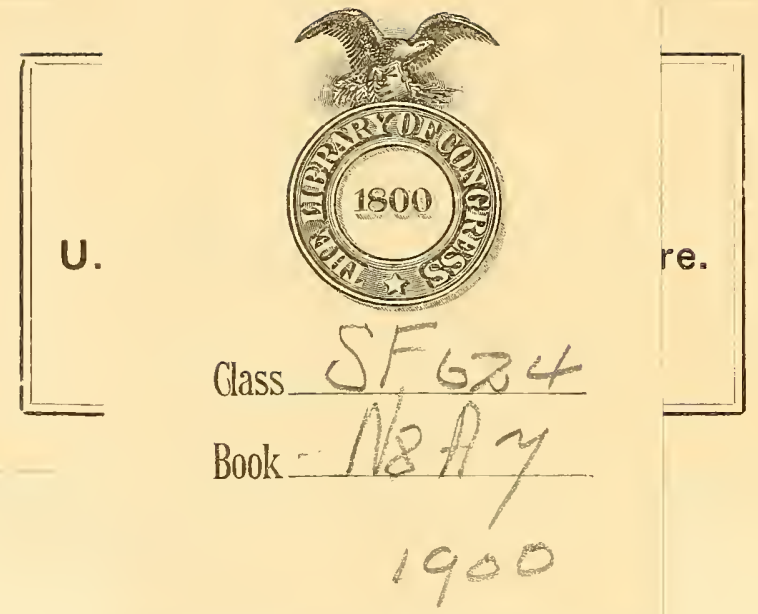
North Carolina Department of Agriculture

BIOLOGICAL DIVISION

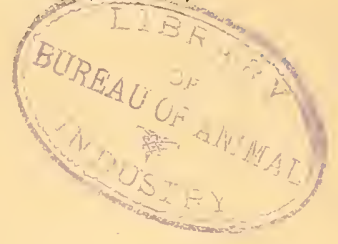

\title{
REGULATIONS
}

FOR THE

\section{Control of Contagious Diseases of Livestock}

\author{
OFICIAL, NOTICES, A DVICE, AND \\ STATE STOCKLAW MAP
}

ISSUED MAY 1,1900

'uthorized by the State Board of Agriculture, December 7, 1899. 


\title{
STATE BOARD OF AGRICULTURE.
}

\author{
OF \\ NORTH CAROLINA.
}

John S. Cuningham, Chairman, Cuningham, N. C.

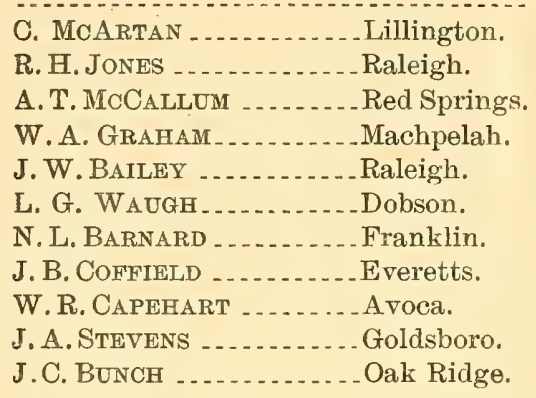

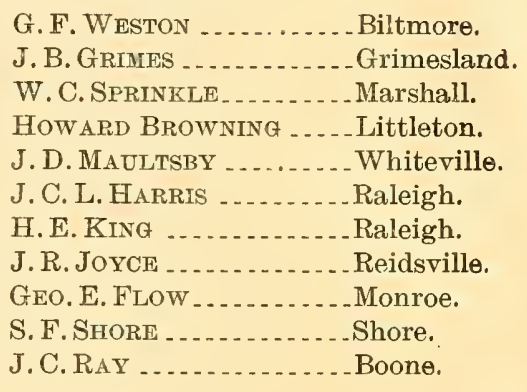

\section{EXECUTIVE COMMITTEE:}

John S. Cuningham, Chairman ex-officio.
J. B. GRIMES.
L. G. WAUGH.
W. A. Graham.
GeO. F. Weston.
A. T. MCCallum.
J.C. L. HARRIS.

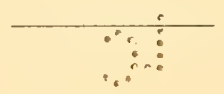

\section{FINANCE COMMITTEE:}

J.B.COFFIELD, Chairman.

N. L. BARNARD.

W. R. CAPEHART.

J.A. Stevens. 


\section{COMMITTEE ON LIVE STOCK CONTROL:}

Geo. F. Weston, Chairman.
J. C. Bunch.
N. L. Barnard.
W. C. SPRINKLe.
C. McArtan.

\section{COMMITTEE ON INSECT PESTS:}

N. L. BARNARD, Chairman.

L. G. W AUGH.

J. B. COFFIELD。

J. A. Stevens.

\section{DEPARTMENT OF AGRICULTURE:}

Commissioner S. L. Patterson. Assistant Commissioner ..... . . . . . . . . ...... W. W. THoMpson.

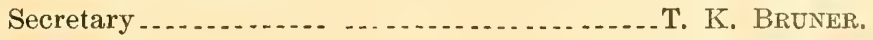
Chemist . . . . . . . Kilgore. Veterinarian.................... COOPER CURTICE.

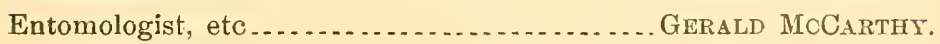




\section{CONTENTS.}

Page.

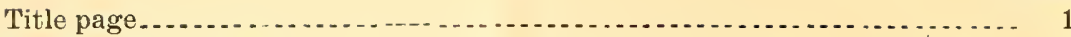

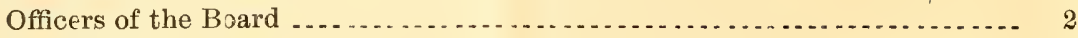

Committees .....

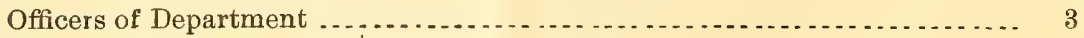

Authority for adopting Regulations............................... 5

Regulations for control of contagious diseases of livestock . . . . . .

Proclamation of the Commissioner for $1900 \ldots \ldots 11$

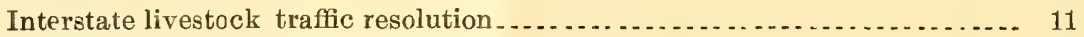

Notice to livestock breeders of North Carolina...................... 12

transportation companies............................... 13

livestock sanitary authorities _........................... 15

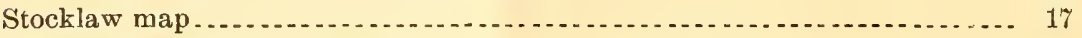

Control of contagious diseases . . . .

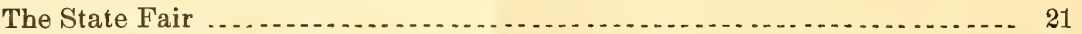

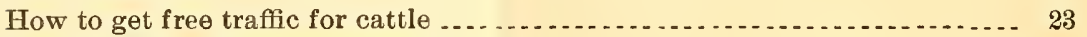

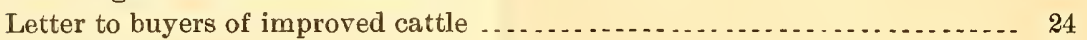

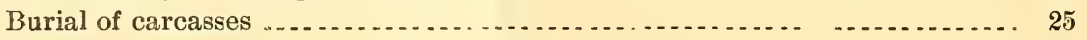

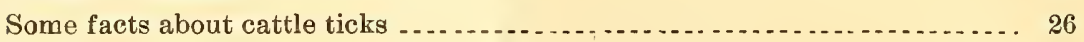

How to kill ticks ..............

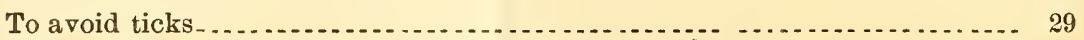

To prevent seed ticks ......

Tick fever and treatment......................................... 30

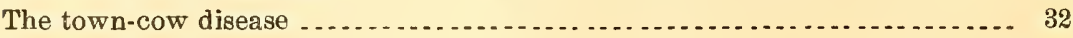




\section{Authority for Adopting Regulations.}

(LAWS OF 1899, ChAPTER 377. )

The General Assembly of North Carolina do enact:

SEcrior 1. That chapter (85) eighty-five of the public laws of eighteen hundred and ninety-seven (1897) and all other laws incousistent with this act be and the same are hereby repealed.

* $\%$ \% $\%$ *

SEC. 7. The Board (of Agriculture) shall investigate and promote such subjects relating to the improvement of agriculture, the beneficial use of commercial fertilizers and composts, and for the inducement of immigration and capital, as they may think proper, but they are especially charged-

(1) With such supervision of the trade in commercial fertilizers as will best $* * *$

(2) With investigations adapted to promote the improvement of milch and beef cattle, and especially investigations relating to diseases of cattle and other domestic animals, and shall publish and distribute from time to time information relative to any contagions diseases of stock and suggest remedies therefor, and shall have power in such cases to quarantine infected animals, to regulate the transportation of stock in this State, or from one section of it to another ; and may cooperate with the United States Department of Agriculture in establishing and maintaining cattle districts or quarantine lines, ts prevent the infection of cattle from splenic or Spanish ferer. Any persen willfully violating such regulations shall be guilty of a misdemeanor.

(3) $* \quad * \quad * \quad * \quad \%$

SEC. 18. This act shall be in force from and after its ratification.

In the General Assembly read three times and ratified this th dar of March, A. D. $189 ?$. 


\section{REGUIATIONS}

FOR THE

\section{Control of Contagious Diseases of Livestock.}

Adopted December 7TH, 1899.

Interstate cattle transportation.

Method of estab lishing infected area.
Section 1. The annual regulations and amendments thereof of the United States Department of Agriculture concerning interstate cattle transportation are hereby adopted as a portion of the regulations of this Board during such time as said regulations are in force.

SEc. 2. The Commissioner of Agriculture shall annually prepare a true map of the infected district of this State and establish such cattle districts or quarantine lines and fix such dates as will comply with the Federal laws and regulations of the United States Secretary of Agriculture and the regulations of this Board, and on or before December 1st of each year shall forward said map or description of said cattle districts and quarantine line and a copy of the regulations of this Board, duly authenticated and certified, to the United States Secretary for his approval. Upon the acceptance of said laws, regulations, cattle districts, quarantine lines, and dates by the United States Secretary of Agriculture, the Commissioner shall make such publication of them as will, in his opinion, be sufficient to fully proclaim said districts, lines and dates, as well as such changes as may be made in the regulations governing them, to the cattle men of the area involved. The Commissioner shall further make, in cooperation with the United States Secretary of Agriculture, such modifications of said districts, lines, dates or regulations as emer- 
gencies arising may demand. The term cattle, as used in Definition cattle. these regulations, shall include bulls, oxen, steers, cows, heifers, yearlings and calves.

SEc. 3. No cattle shall be transported, driven or caused to be driven or allowed to stray from any place in the quarantined district of this State, as determined according to section 2, into those districts exempted from the Federal quarantine by the United States Secretary of Agriculture between such dates as the said Secretary and the Commissioner of Agriculture shall determine upon: Provided, controlling cattle that this order shall not apply to cattle transported by rail consigned through such exempted districts to other States, which are transported in accordance with the Eederal regulations relating to interstate transportation of cattle.

SEc. 4. No cattle originating in the area of other States proscribed by the Secretary of Agriculture of the United States as having a contagious and infectious disease, known Forbidding entrance of cattle from quarantined districts of other states. as splenetic or Southern fever among its cattle, shall be transported, driven, or caused to be driven, or allowed to stray at any time of the year across or into any portion of this State in which cattle are declared by the said Secretary of $\Lambda$ griculture as being exempted in whole or in part from the pperations of the Federal regulations concerning transportation of cattle originating in certain areas: Prorided, this section shall not apply to interstate traffic in cattle by rail or boat transacted in accordance with the Federal regulations relating thereto, or to uninfected cattle exempted by special permit of the United States Secretary of Agriculture: Provided further, that from Norember 1 to December 31, inclusive, or such other dates as may be agreed upon between the said Secretary of Agriculture and the Commissioner of Agriculture of this State, cattle may he so transported, driren, caused to be driren, or allowed to stray when found free of infection upon inspection by officers of the United States Department of Agriculture, or under such regulations as may be hereafter agreed upon by the said Secretary and Commissiner. 
Infected cattie infect and quar antine exempted districts.

Cattle ticks infect and quarantine exempted districts.

Tick infested cattle notallowed on highways.

Orders Commissioner to investigate reported disease.
Sec. 5. When cattle from the infected areas, as defined by the Secretary of the United States Department of Agriculture in the annual regulations concerning cattle transportation and the amendments thereof in the regulations of this Board, shall have moved or been moved in violation of these regulations or their amendments, the feeding places, yards and pasturages upon which said cattle have been moved shall become infected districts and subject to the same regulations as other infected areas; the limits of said infected area shall be defined by the extent of range allowed the animals from the infected areas and by the efficiency of the exclusion of other cattle from said infected districts: Provided, that all other cattle may be removed by permission of the Commissioner or his legal representative, from these newly infected districts at any time within twenty days, comnting from the first day on which cattle from the infected areas invaded these districts. All cattle driven, pasturing or straying on an infected district after the twentieth day as aforesaid, shall be considered as infected cattle and subject to the same regulations as cattle from the infected areas.

SEC. 6. Notice is hereby given that cattle infested with the "Boophitus bovis" or Southern cattle tick, disseminate the contagion of the splenetic or Sonthern ferer (Texas fever); therefore cattle which are found in the exempted districts infested with the Boophitus bovis ticks shall be considered as infectious cattle and shall be subject to the regnlations relating to cattle originating from proscribed areas.

SEc. 7. To cattle infested with ticks shall be led, driven or cansed to be driven, or allowed to stray upon the highways or prblic roads of the exempted districts, or of any "stock law" or "no-fence law" district in this State, or be received into anv market or stock-yard of these districts.

SEc. S. When the Commissioner of Agrieulture shall have good reason to believe, or have received credible in- 
formation that a contagions or infections disease exists among the livestock of this State, or, in the case of the non-quarantine territory, that cattle ticks exist on cattle therein, the Commissioner shall cause the State Veterinarian or other assistant to investigate said livestock, premises and buildings, where the livestock suspected of being diseased or harhoring the cattle ticks are kept, and exannine said livestork or animals, which have come in contact with the aforesaid livestock, for the presence of said snspected lisease or cattle ticks.

SEC. 9. Whenerer any contagions or infections disease Orders Commisof livestcek shall exist in any portion of the State, or cattle tine infected andticks in excmpted districts, the infected livestock or infectud material which may convey disease, or both, or animals which may have cone in contact with such disease, shall be quarantined hy the Commissioner of Agriculture on the premises, or in lots or buildings in which they may be founcl, mutil such time as danger from the spread of disease is past and all necessary disinfection is completed. The Commissioner of Agriculture is hereby directed to make, publish and enforce all other rules and regulations temporarily necessary to prevent the spread of contagions and infretions rlisease in livestock, and cause the disinfection of infected premises by the tenant, owner or owners, whenever and wherever necessary.

SEc. 10. Whenever any contagious or infections disease Furbids entrance prevails among livestock in any State or Territory of the of cut ce tificate $\begin{gathered}\text { outh } \\ \text { when disease }\end{gathered}$ United States, or any foreign conntry, livestock from saif Siates. State or Territory shall not he arlunitted to this State except when acempanied by a description or tag, or both, and certificate of ahsence of disease, or of entact with diseased animals, for thirty days prior to shipment of sairl livestock. which eertificate shall be approved ly the State or Territorial Cattle Commissioner, Board of II calth, or V'eterinarian in eharge of the execution of livstock sanitary latws in the State whenee the eattle originate, or, in the aase of 
Empowers Commissioner to tem porarily quaranapplication.

- मi. IT:

- II ITPJ] D

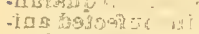

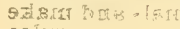

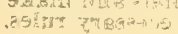
sioner to publish regulations,

maps, etc

a foreign country, by the Secretary of the United States Department of Agriculture, and be submitted to and acceptable to the Commissioner of Agriculture; said certificate shall be presented before or at the time of the importation of the said livestock into this State.

SEC. 11. The Commissioner of Agriculture shall, upon application of the Superintendent, or authorities, or livestock men of any county temporarily forbid the entrance of any species of livestock from any infected county or counties until such time as danger of infection from said infected county or counties is past; this local quarantine shall be published in local newspapers and sufficient notices shall be posted by the Commissioner of Agriculture on the lighways at the county line.

SEc. 12. The Commissioner of Agriculture is hereby directed to publish the cattle quarantine laws and these regulations for control of contagious diseases of livestock, together with such maps as may be necessary, and such other information as may pertain thereto, and distribute among the cattle men of this State.

SEC. 13. These regulations shall be in force on and after January 1, 1900, and supersede those adopted by this Board June 2, 1899.

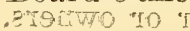

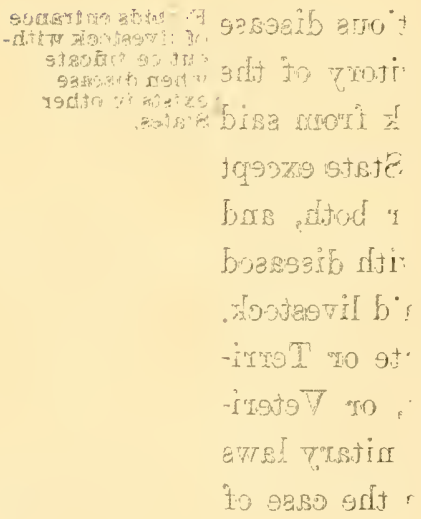


PROCLAMATION OF THE COMMISSIONER FOR 1900.

\section{N. C. Department of Agriculture, Raleigh, January 20, 1900.}

To Whom it May Concern:

In accordance with the agreement made between the Secretary of the United States Department of Agriculture and the Commissioner of this Department, as provided in the regulations controlling cattio traffic administered by these Departments, the following countie have been exempted from the annual Federal quarantine: Alleghany, Ashe, Watauga, Mitchell, Yancey, Buncombe, Madison, Henderson, Transylvania, Haywood, Jackson, Macon, Swain, Graham, Clay and Cherokee.

All cattle owners and others are hereby notified that the quarantine line is as described in the Federal regulations, Bureau of Animal Industry, Orders Nos. 49 to 55 inclusive, and future amendments, and that no cattle may be driven or allowed to stray from the remaining counties of this State or from other States or portions thereof which are included in the Federal quarantine into any portion of the abovesaid counties after January 1, 1900.

The enforcement of these orders strictly and completely will secure for the herein-mentioned counties an uninterrupted traffic with the open markets.

Very respectfully,

S. L. Patterson,

Commissioner.

\section{INTERSTATE LIVESTOCK TRAFFIC RESOLUTION.}

At the meeting of the Board of Agriculture held in Raleigh March 7, 1900, the following resolution, proposed by the Committee on Contagious Diseases of Cattle, was passed without dissent. 
Wheress, a regulation has already been made by this Board providing that all cattle shipper here or otherwise introduced from other States, where contagions diseases exist, shall be accompanied by certificates of good health, and

Wheress, this regulation has not ret been put in force, and further, many other States have already taken similar action, be it

Resolved, That the Commissioner of Agriculture shall be instructed at once to take the necessary steps to secure the enforcement of this regulation.

In accordance therewith the following notices are issued:

1. To stock-breeders of North Carolina.

2. To all railroad, express and steamship companies, and common carrier's doing business in North Carolina; and

3. To livestock sanitary anthorities.

These notices call attention to the enforcement of the regulation in question, and it is expected that all will carry ont its spirit and letter.

S. I. Patterson,

Cooper Certich, Commissioner.

Teterinarian.

\section{N. C. Dephrtient of Agriculture,}

Raleigit, May 1, 1900.

To Stock-Breeders of North Carolina:

You are hereby notified that dangerons, destructive, communicable diseases exist in varions parts of the United States; to-wit: Glanders and farcy in horses and mules, cattle ticks on, and tubereulosis in cattle, scab on sheep and other animals, and log cholera in swine.

Section 10 of the Regulations of the Board of Agriculture, adopted December 7,1899 , to prevent the introduction of such communicable diseases, forbids the admittance into this State of all livestock except when accompanied by a certificate of the livestock sanitary anthorities of the State whence the livestock originate, that the said livestock are healthy in every respect.

In purchasing lirestoek outside the State inform the breeder of whom you buy that a certificate of health obtained from his livestock 
authorities and bearing the endorsement of this Department must accompany the shipment in order to aroid tronble, vexations delays, extra expense and introduction of disease. The certificate must include a tuherculin examination of cattle for all purposes other than immediate slaughter, or steers for feeding or work.

By careful attention to these points the breeding herds of this State may be kept free from diseases which are now harassing breeders of other States.

Fifteen other States have now legislation to compel the examination of breeding and dairy stock before or at the time of importation.

When breeders design shipping to those States they should comply with their regulations, and aroid delays and entailed expense upon the arrival of the stock in those States.

Those transferring cattle within the State are especially cantioned alont accepting stock that have not been tested. Examinations save much tronble and loss, and guarantee healthy herds. if persevered in.

Refer any question upon sanitary matters to this Department.

I am rerr respectfully rours,

S. L. Pattersor,

Cooper Curtice,

Commissioner.

Teterinarian.

\section{N. C. Departalext of Agriculture,}

Raleigh, May 1, 1900.

To all Railroad, Express and Steamstip Companies and Common Carriers Doing Business in North Carolina:

You are hereby notified that by virtue of the power conferred in the Act of General Assembly of North Carolina, entitled "An Act to Repeal Chapter Eighty-Five of the Laws of 1897, and to Reform the Department of Agriculture, Immigration and Statistics," ratified March 4, 1899, which act directs the Board of Agriculture to quarantine animals infected with contagions diseases, to regnlate the transportation of stock in this State, or from one section of it to another, and to cooperate with the United States 1)epartment of Agrienlture in establishing and maintaining cattle districts or quarantine lines, to prevent the infectoin of cattle from splenic or Spanish 
fever, etc., the Board of Agriculture of this State did, on December 7 , 1899. make such regulations to take effect January 1, 1900, and supersede regulations adopted by it on June 2, 1899.

By consulting the enclosed regulations and those of the United States Department of Agriculture promulgated at various dates you will note that they are of particular interest to you as common carriers of iivestock and as participants in the development of a livestoch industry in this State. The particular orders of the United States Departnent of Agriculture referred to are its organic law creating the Bureau of Animal Industry, approved May 29, 1884; the recent amendments thereto: B. A. I. Order of April 15, 1887; its amendment dated December 13, 1895 ; and B. A. I. Orders Nos. 49, 54, 56 and 57 .

Tour attention is invited to the following points:

1. Under these regulations you can not legally handle any cattle consigued from the quarantined portion of the United States to the comties of this State that have been exempted from quarantine by the United States Secretary of Agriculture.

2. Under section 7, of the State Board regulations, you can neither legally deliver nor receive any tick-infested cattle into stockyards of any exempted or any stocklaw districts of this State. By carelessness of your agents in this respect the cattle pens west of the Blue Ridge have been closed by the Federal Gorernment, and may be again, thus causing quarantine of all stock in that region. The enforcement of the order in the stocklaw region east of the Ridge will hasten the day when it mav be relieved from the burdensome restrictions of cattle traffic now placed upon it.

3. Under section 10, of the Board regulations, you can not legally deliver livestock shipped into this State, unless the animals are accompanied by a certificate of absence of disease, given by the livestock sanitary anthorities of the State whence the livestock originates, and approred by this Department. Shipping tags bearing the acceptable form of certificate, will be supplied to sanitary authorities by this Department.

Owing to the presence of communicable diseases in other States, fifteen of these have enacted laws exchuding diseased livestock. In order to prevent their shipment into this State the above regulation 
has become necessary. I few diseased animals introduced into our breeding herds will produce injury from which it will take years to recover. In demanding that the certificate of health shall accompany each shipment, the transportation companies are reliered of attention to the matter further than to see that each shipment bears the certificate, and refuse it without. This method least interferes with traffic when once understood.

Your anthority for refusing to ship livestock without certificate is contained in B. A. I. Order, dated December 13, 1895. This prohibits the interstate transportation of animals affected with hog cholcra. tuberculosis, or sheep scab, and B. A. I. Order To. 56, dated December 28, 1899, which adds other diseases and livestock, including horses and goats, to the list. Since transportation companies can not act as experts in the detection of diseases in the livestock submitted to them for transportation, they may well insist that such stock be certified by the authorities of the State where accepted.

In assisting in this morement to secure healthy breeding stock for the farms in this State. and in preventing the spread of dangerous communicable diseases, you will aid in the upbuilding of the farming industry, and add materially to the increased traffic which is dependent rpon it.

I am very respectfully yours,

Cooper Curtice,

S. L. PATtERSON,

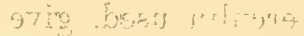

Teterinarian.

N. C. Departiment of Agriculture,

Commissioner.

Rateigh, May 1, 1900.

To Livestock Sanitary Authorities.

Gextlenex:- Tou are hereby notified that the Board of Agriculture of this State has passed the accompanying regulations, which inchudes one to prevent the introduction of diseases into this State through the importation of diseased livestock from other States or foreign comntries. See section To. 10. Ton will please notify you? breeders of this action.

The word lirestock as therein used is synonymous with the word animals as used in the Federal regulations. See B. A. I. Order No. 
56, page 2. It inclndes: Ilorses, asses and mules, neat cattle, sheep, and other ruminants, and swine.

The word disease especially includes any of the following:

Glanders and farey, distemper, anthrax, Texas or splenetic fever, cattle ticks (Brophitus boris). tuberculosis, actinomycosis, variola, foot-rot, scah, hog cholera and swine plagne, as specified in said order No. 56, lut does not exclude other communicable diseases.

Shipping tags which must accompany shipments into this State will be furnished each Livestock Sanitary Board, or other anthority on application. When nsed they should each be signed by the ehief oficer of the Board or ther anthority, and its Yeterinarian, in the places left for the purpose. Descriptions of the animals must include such data as will serve to identify them, and must be written on the back of the tags.

The certificate which is acceptable is a duplicate of the shipping tag, and must lie sent to this Department. All practicable known means of determining the ahsence of disease must he need by the inspector. A swom copy of the tuberculin test in case of cattle designed for breeding or dairy purposes, must accompany the certificate. The tuberculin test should state the amount and manufacturer of the truberentin used, give the temperatures taken at two-hour intervals from the tenth to the eighteenth hour after injection and other customary data. The test shomld especially state at what times previous tests had heen made and the results. Examinations must be made by men approved by you.

In insisting that the State which your represent presents satisfactory eridence that livestock destined for this State are healthy, this Department takes what it believes is the most economical method of dealing with livestock control for all concerned. and therebr aroids tedions delays and expenses after shipment of such livestock, which delays are incidental upon enforcement of quarantines and inspections en ronte.

Your State has the necessary means of investigating suroundings and is especially interested in the upbuilding of its livestock industry and the reputation of the bealthfulness of its stock as breeding animals. 



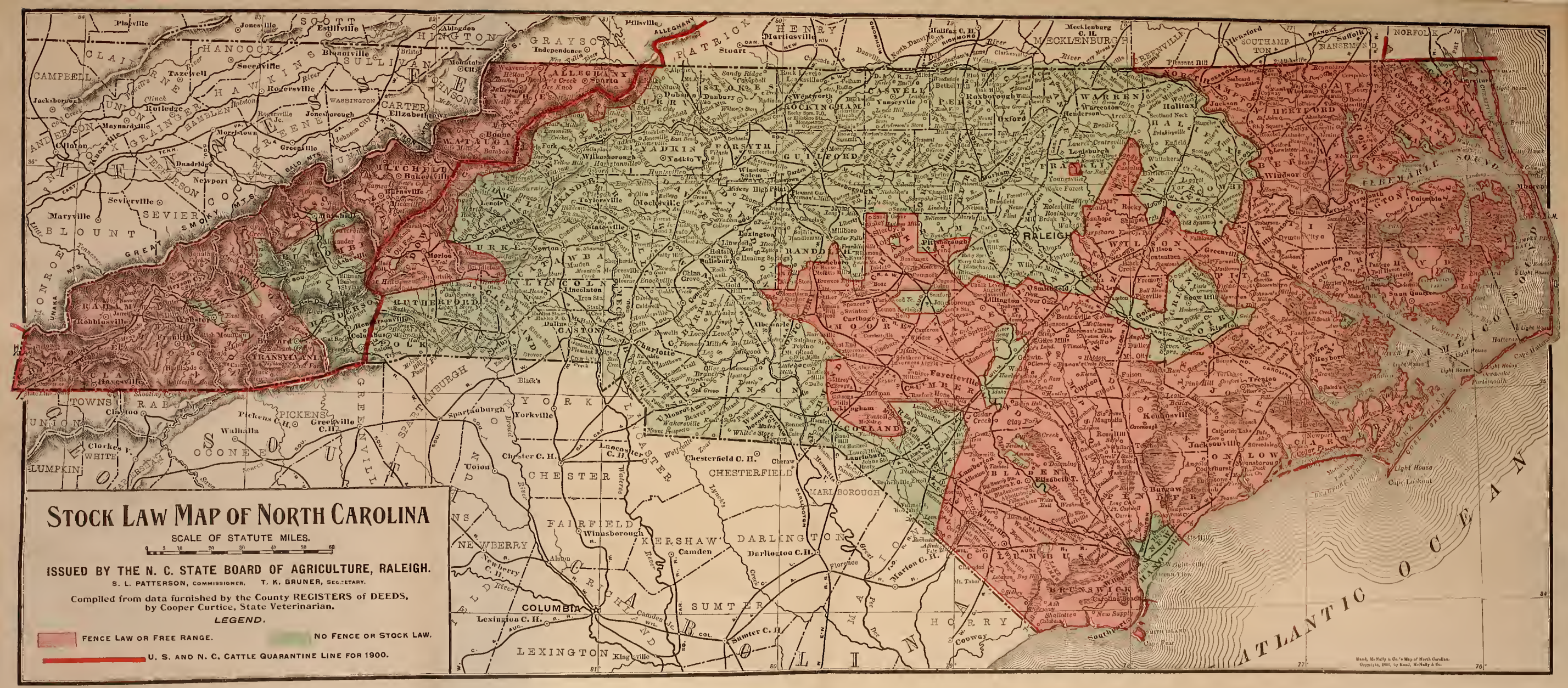




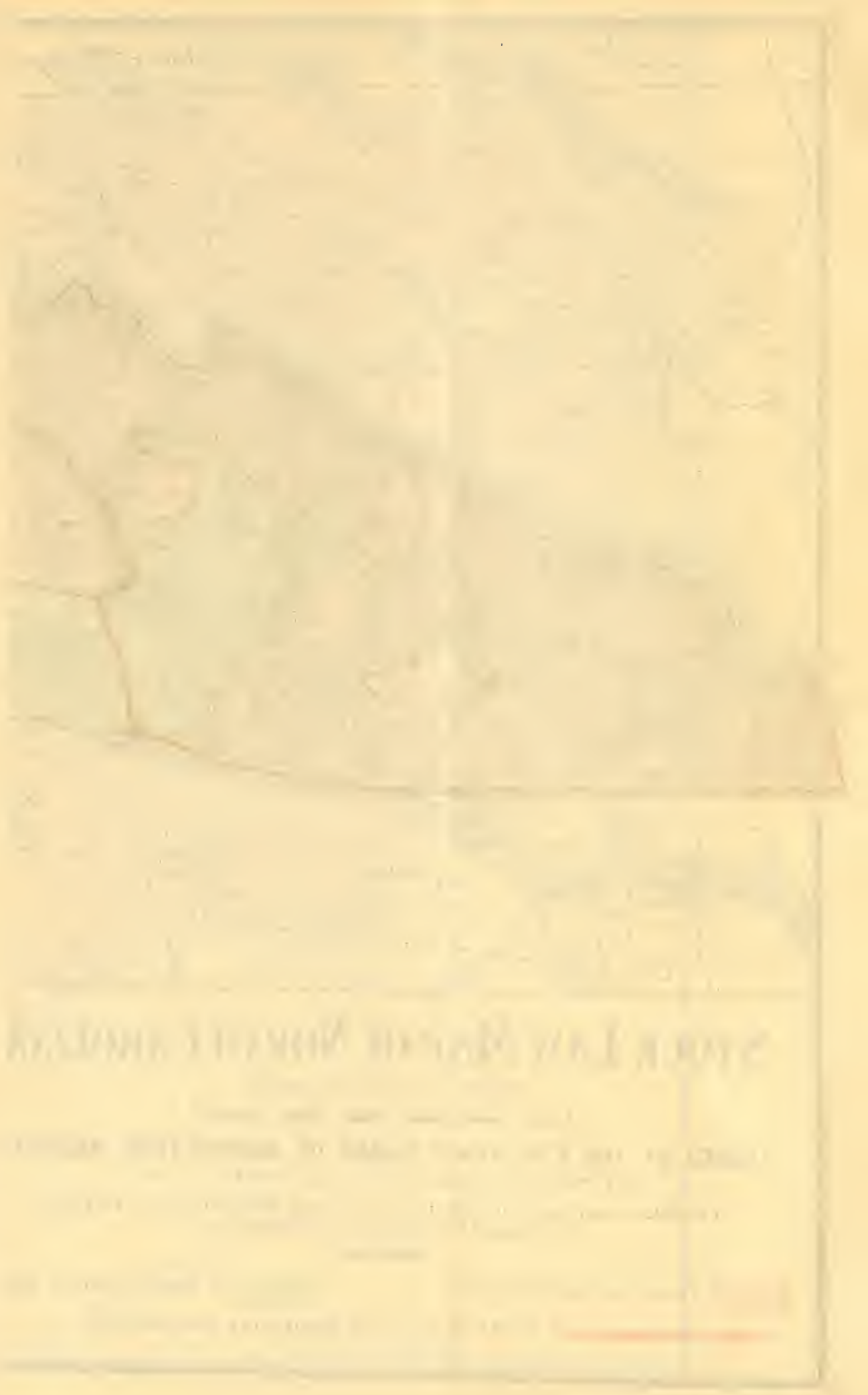


This Department in turn proposes to furnish certificates of health for all livestock exported to such of the States as demand them.

I. am very respectfully vours,

S. L. Patterson,

Cooper Curtice,

Commissioner.

Veterinarian.

\section{STOCKLAII MAP.}

Tho storklaw map issued in this bulletin is represented as bcing fairly accurate, and as much so as it could be made at the time of compilation. Should there be noticeable inaconracies, this Department will place on file all corrections sent to it.

Corrections: Matthews Township, in Chathan County, has adopted stocklaw since the map was ordered. The small, isolated arca of free range in Franklin Comnty has also been abolished. An area of firee range, not noted in the map, still exists in Nash County, The area of stocklaw in Madison Comnty is much larger than represented, and will be corrected in a future edition of the map shonld sucls prove desirable.

From all places in the stocklaw area comes the report of the improved quality of the livestock and the diminntion of diseases other than tick fever. The numbers, while at first diminished, are thought to increase and become abont the same as before the adoption, and in scme instances even more than during free range. The manifest benefits of stocklaw are such that nnirersal approval comes from all within that area, and nany without. The continually decreasing supply of fence timber, the cost of wire fences, and the increased acreage of cultivated lands worked by those who depend npon commercial fertilizers rather than livestock for enriching their land, will eventually end in the arloption of the stocklaw for the entire area of the State.

By adopting stocklaw the necessity of providing pasturage at al] seasons of the year becomes apparent, and is met hy the stockowner. In feeding stock the fact that better bred animals rield better returns for the lahor expended than the old strle scrul, stock, induces men to improve their farm animals, and care even more for them. Tho 
reveme saved in fertilizers by confining cattle in pastures and yards, combined with the diversified farming that accompanies stockraising has been such that more and more are entering stockraising and stockfeeding, and adding to their prosperity.

A glance at the map will show that from modest beginnings, made under a local option law about a quarter of a century ago in the vicinity of Mecklenburg and Cabarrus comnties, the stocklaw has spread until it oceupies more than half of the cultivable areas of the State. The portions it does not ocenpy are for the most part either heavily timbered momntain lands or the pine barrens of the southeast, or the poquosin and swamp districts of the east. Even in the mountains there are counties where the cattle are kept in pastures, and although they have not officially adopted stocklaw, their conditions are abont the same as thongh they had. The comnties of Ashe, Alleghany and part of Watanga, are referred to.

One momtainoms county east of the Blue Ridge is free range, and all comties, excepting Polk, bordering it, have a strip of free range next the Ridge. The harmful effect that these areas have in perpetmating ich and keeping the foot-hill counties in quarantine do not compensate those counties for the advantage derived from the free pasturage therein. They should be abolished.

With the adoption of stocklaw for the foot-hill comties and their disinfoction and an eastward setting over of the quarantine line, there will be no danger so far as tick infection is concerned in continuing the free range of the mountains. The climate therein has always exterminated the ticks under the most adverse conditions.

There is, however, a growing disposition in the mountains to adopt stocklaw, and take better care of eattle, and increase their improved stock and pasturage. The day is not far distant when large districts will be added to the alrearly large areas in the mountains.

The entting off of large areas from the free range in Nash, Wilson, Johnston and Wayne comties, already shows that the time is not far distant when that now nearly isolated area will have entirely disappeared.

The recent action of Chatham County in its adoption of stocklaw for a whole township, the isolated areas in Moore, Cumberland and Finnett counties, as well as recent meetings held to consider the 
adoption of stocklaw in various districts, are very farorable signs pointing to the adoption of stocklaw in that region which is even now almost separated from the eastern free range by a stocklaw belt.

The adoption of stocklaw is argued against by some on account of the expense to the region adopting it of the fence to be made. An examination of the map shows that less than twenty miles of fence would completely cut off the Wilson district, would all the adjoining counties agree to it. This mileage, in contrast to that now umnecessarily lept up, is nnimportant. The greater part of the distance is already fenced.

Less that twenty miles of fence would also cut off the Moore-Harnett cominty area, and permit the use of hundreds of miles of fencing, now kept up at great expense, for the enclosure of pastures in which cattle and hogs can be and will be better fed than now. In addition, the expense now entailed by fences, can be turned into buildings and other permanent improvement.

While the adoption of stocklaw by the entire State will not soon be realized, the writer can not refrain from pointing out that its adoption would be a great blessing to the free range counties and a protection to the livestock of the rest of the State from communicable diseases. It may here be pointed ont that the day is surely coming when all of the stocklaw counties will be allowed free traffic in cattle with all markets of the world. At that time, if not before, all intercourse by stcer teams and cattle traffic between the free range infected by cattle ticks and the stocklaw counties, will be stopped, and the chief markets of the former for beef cattle in this State be cut off. The future of the livestock industry of this State for all parts will be aided by the adoption of universal stock laws.

That such action is legitimate and just is at once apparent when the menace and loss to the industry of the State by cattle ticks and hog cholera, neither of which can be restrained under present conditions, is considered.

The adoption of the stocklaw fence as a quarantine line, which will eventually follow, will not give protection to some of the citizens of the free range who are entitled to it. A large and growing number now desire to raise stock to feed their surplus roughness to. These can feel no safety, and will always be in great risk of losing their 
animals, so long as diseases are allowed to exist uncontrolled. These men are entitled to the protection of the State, and their need is sufficient warrant for the State to legislate in their behalf.

111 but three counties in South Carolina, and the greater part of all comties in Georgia, now have stocklaw. There can be no greater justification of the justice and the good effects of laws than their voluntary local adoption by nearly all counties of three large States. These laws having passed their experimental stages. there remains bet their adoption by the State for the few districts yet remaining.

\section{CONTROL OF CONTIGIOUS DISEASES.}

Sertion s of the State Board regulations directs the Commissioner of Agrienlnure, on information that contagions disease may exist in this State, to investigate the ontbreak. Section 9 direets that when such disease is found that every means shall be taken to prevent its further spread.

These two sections contain all that is necessary to stop the spread of any outbreak, and are all the law that this State has upon the matter. The lepartment of Igrieulture is the livestock sanitary anthority to whom the farmers must look for protection from commmicable diseases. In examination of section 9 shows that there can be no attempt to destroy anyone's infected stock, but that they may be confined by the owner until there is no longer any dauger.

It will be noticed that only contagions or infections diseases are mentioned. It is not held anywhere that it is the business of the State to doctor animals that are afflicted with other non-communicable diseases. That is the business of the practicing veterinarian. This Department, however, answers such questions relating to these diseases as may be answered, but fears that many of the letters of inquiry and the answers arrive too late to be of especial use.

There are ontbreaks of disease which are produced by food or other causes in many animals in such manner as to simulate contagions diseases. These should be reported promptly to this Department. Ther may le prevented.

All ontbreaks of diseases in animals should be reported, that this 
Department may keep a record and take means to investigate, if necessary, and stop them. It is undoubtedly true that there is some hog cholera in the free range districts, but if these cases are not reported this Department can not know how much there is of the disease, where the centers of infection are located or other facts necessary in order to intelligently pursue any plan of prevention.

The same is true with regard to blackleg in young cattle, a disease occurring in some of the mountain counties. More accurate reports will help all concemed.

It is thonght on accomnt of the campaign against ticks, that this Department does not deal with any other diseases than those of cattle. Those of horses, mules, sheep, goats, swine, and poultry are also included. The activity on account of splenic or tick fever is because of the greater damage done, and the more pressing need for immediate attention. Other animals will be attended to as the occasion arises.

Let all be prompt to report and care for outbreaks in their own livestock, and it may be that they will save more than though they avoided information on the matter.

Knowledge of sanitary matter's saves much to the farmer.

\section{THE STATE FAIR.}

The exchsion of Southern cattle from Northern markets, except for immediate slanghter, has, during past years, been the canse of keeping Northern exhibitors from the Sonthern fairs, on account of the fear of the loss of their cattle from tick fever, and their inability to return their cattle to their homes after' exhibition.

The accompanying correspondence and B. A. I. Order No. 60 show the steps that must be taken to secure exhibitor's the privileges of returning, and assure them that no harm will come to their cattle while here.

The presence of Northern cattle at the Fair last year' was on account of similar arrangements made by the Veterinarian with the U. S. Department for the fair anthorities. It is expected that beef and dairy cattle may be made a special featme of the livestock exhibit this season. 
N. C. Department of Agriculture, Raleigh, April 3, 1900.

Hon. James Witson, Secretary of Agriculture, Washington, D. C.

SIR:-I have the honor to repeat the request of last year regarding the exemption of the State Fair Ground at Raleigh, N. C.

The State Fair anthorities represent to me that these grounds have not been invaded by any cattle since the last Fair in 1899, and that none will be permitted on them until the fortheoming Fair.

All cattle coming from north of the quarantine line are unloaded directly from cars into the grounds, and reloaded there when the exhibition is finished.

All cattle entering the ground from the surrounding city at the time of the Fair will be duly inspected, and no infected animals permitted to exhibit.

We beg that you may consider the proposition favorably, and grant to our transquarantine visitors the right to return after their exhibition here.

I am very respectfully yours,

Cooper Curtice,

Veterinarian.

(B. A. I. Order No. 60.)

\section{SPECIAL ORDER PROVIDING FOR RETURN TO NON-INFECTED DISTRICT OF CATTLE EXHIBITED AT STATE FAIR AT RALEIGH, N. C.}

(Supplementary to B. A. I. Order No. 49.)

U. S. Department of Agriculture,

Office of the Secretary,

Washington, D. C., April 6, 1900.

It is hereby ordered, That cattle from above the quarantine line, and which have been shipped directly from the non-infected district to the fair grounds at Raleigh, North Carolina, for exhibition at the State Fair of 1900, and which are returned without having been 
unloaded elsewhere, be permitted to return as uninfected cattle, providing they are accompanied by a certificate of the Veterinarian of the Torth Carolina Department of Agriculture showing that they have had no opportunity to become infected with the tick (Boophilus bovis) while at said grounds.

(Signed) JAMES WILson,

Secretary.

\section{HOW TO GET FREE TRAFFIC FOR CATTLE.}

The Federal quarantine of the cattle traffic of 81 counties of this State, while the traffic of 16 others is not interfered with, leads to a consideration of the means by which they too may obtain free traffic. 'The conditions of the stocklaw area are such that but little effort on the part of cattle owners is necessary to free its entire traffic.

Each county interested should organize livestock clubs. When these are composed of the leading breeders their power for good in the county is felt, and the purposes for which they stand are advanced. Such clubs should have a chairman, a secretary, and an executive commitee. The clubs should have the improvement of the livesscr. of their counties as their fundamental object. Purchase of breeding animals and marketing products by cooperation may enter into their business later.

The clubs should, through their members, investigate their counties, and learn on what farms ticks are present. When it is ascertained that they are either entirely absent, or on so few farms that lliese may he safely quarantined instead of the whole countr, they should apply for relief from quarantine to the Commissioner of A griculture.

When they are situated next the quarantine line, this can be attained at least by the next season and possibly by inspection during the same season. The relief from quarantine carries with it the obligations of the exempted counties; one of which forbids the entrance of cattle from quarantine counties, and the enforcement of the State Foard regrulations by the cattlemen. When situated within the quar- 
antined area it is possible that by exclusion of other cattle, exemption after inspestion may be granted by the Federal Department of Agriculture. Ln any case the dangers of losing cattle from tick fever will be done away with.

If complete exchusion of tick-infested eattle of any county from the free range is d sired by local quarantine, the Commissioner will, upon the appeal of the authorities the Superintendents, or livestock mon of that county, order such quarantine as directed in section 11 of the regulations.

All owners of ticky cattle should be informed of the embarrassment to the cattle traftic they are keeping up by permitting ticks to infest their heir and their attention directed to the means of destroying; them.

Whether chuls are formed or not each individual shonld make it his business to prevent ticky cattle from being driven on the public roads. Igents may be appointed by elubs to look after this. To single law can so quickly bring men to cleaning tieks from eattle as the knowledge that they are harmful, and that their being on cattle may cause their proseeution.

No ticks, no quarantine.

\section{N. C. Departinent of Agriculture,}

Rileigh, May 1, 1900.

To Buyers of Improved Cattle:

Acclimation disease in bulls has for years been a bar against improvement by introducing thoronghbred stock.

By observing a few precantions bulls may be brought to this State to any portion of the "stocklaw" district at any time of year, without langer of loss.

If there are no cattle ticks on the cattle of the farm: Either transport the imported bull in a wagon from the depot not unloading into the cattle pens), or drive him in the middle of the road after greasing his legs, and do not allow him to touch grass by the way. Grease them again when they arrive. Or on infested farms prepare a vard and shed in a field which has been eultivated during two years 
and no cattle allowed thereon. Build a donble fence, the inside being of high, tight boards, and the outer at a few foet distance of wire that will keep stock away. Proride shade.

Set aside a special pen in which cows may be serred. Clean each cow of all ticks before admitting her, and thoronghly grease her. When served take the cow away from this yard.

Feed and water correctly, and allow plenty of exercise.

$\Lambda$ certificate stating that the bulls are not infected with any communicable disease, and signed by the anthorities of the State they started from, should accompany each importation. Buy any breed of eattle where quarantine regulations permit.

Cooper Curtice,

Teterinarian.

\section{BURIAL OF CARCASSES.}

There is no more certain way of spreading some diseases than by leaving carcasses exposed to carrion-feeders.

Of the animals which spread hog cholera, the buzzard easily leads. Allowing the hogs to get at the carcasses is also a prolific means. If carcasses were deeply buried, or destroyed by other means, as burning or rendering into soap-grease, much loss wonld be saved.

The least that careasses are moved about, and the most efficient means taken for their disposition, the better. The more careless a commmity is in regards to the disposition of careasses, the more will it suffer on account of communicable diseases.

This Department has full autlority to order the burial of animals dead of contagions discases, and will do so whenerer the sentiment of any community demauds.

\section{PUBLTC TELEARE.}

The enforcement of the State Board regulation forbirling the use of the public roads in stocklaw counties by tick infested cattle, will, if enforced, prevent the spread of ticks. 


\section{SOME FACTS ABOUT CATTLE TICKS.}

Boopkilus boris, Curtice.

Cattle ticks cause the quarantine of eighty-one counties in North Carolina.

The cattle traffic in thirteen States and the Indian Territory is serionsly interfered with on account of cattle ticks. The cattle traffic in other States is constantly menaced in summer-time by them.

Cattle ticks ocur and transmit disease in South America, Sonth Africa and Australia.

Cattle ticks tax cattle orners by:

Making cattle poor,

Hindering gond breeding,

Killing cattle,

Shutting off markets, Preventing immigration,

Cattle ticks are instrumental in cansing:

Tick ferer,

Lowering land valnes.

Red water,

Distemper,

Texas fever,

Splenic ferer,

Spanish cattle ferer.

Bloody murrain, Pasture poisoning, Acclimation ferer, Torm-cow disease, Sonther'n cattle ferer,

Cattle ticks kill more cattle than all other diseasis in the Sonth. They are loathsome, detestable, destructive, virulent, venomous, but easily exterminable pests.

Cattle ticks are called: "Oldfield ticks," "Shingle ticks," "Blue ticks," "Fever ticks," "Dog ticks," and other names.

All large female ticks look much alike. They are all harmful, and live upon blond. The three most common kinds of ticks are: The cartle tick, which has a chestnut-brown head; the "lone star" tick, which has a bright metallic spot on the back of its head; and the dog tick (also called the deer tick, bear tick or terrapin tick), which has a whitish horder around its head.

Life History of Ticks.

1. Female drops to the ground.

2. Interval two days. 
3. Egg-laying ocenpies two weeks.

4. Hatching occupies three weeks.

5. Seed ticks lie in wait for cattle.

6. Attached to cattle from three to four weeks.

7. Old ticks drop off, lay eggs, and die.

Least time from the egg to egg-laying, six weeks.

The shortest time of life cycle is in hot, moist weather. The longest time is in cool weather. It may occupy from two to three months.

Seed ticks may lie in wait on grass for months. In bottles with moisture they have been kept for four months without food. They will hatch from eggs kept in stoppered bottles or wrapped in brown paper, and laid away in a warm, but not ton dry, place. All should try this. In dry bottles, and in papers kept in dry places, they perish more quickly. They do not live on plant food, nor grow in the least before they get on cattle. Probably all die in winter time.

. Tick eggs laid in fall on the approach of the winter, probably do not all perish but survive in the egg condition, and hatch on the return of warm weather.

In districts where the cold season is relatively short, it is probable that ticks are never absent from cattle from one season to another, and these perpetuate the pests.

Ticks never migrate far of themselves. They are always carried by cattle from place to place. The seed ticks may crawl to the nearest grass stalk and climb to the top. Bunches are frequently seen thus. They have not been known to cross a fence into the next pastures. They may be blown there by the wind or carried on straws or washed there by rains. These aceidents do not often happen, so that it is nniversally accepted that a fence is security against tick fever. But their presence in adjoining pastures is a constant menace to others.

Cattle that have been infested by ticks may be known by the scars - little pits - that may be seen on the inside of the thighs. The scars are made by short hairs. Such cattle are immunes, and may be pastured anywhere withont danger.

Calves when infected by ticks get sick, recover, and are thereafter not affected by ticks. Older cattle rarely live through the disease when inoculated by ticks for the first time. 


\section{HOW TO KILL TIOKS.}

\section{By CoOper Cuktice; Veterinarian.}

The hand is the best and the cheapest picking machine. It is always ready and always sure. Hand-picking for large ticks is the cheapest method for all farms east of the Mississippi River. The ticks should be preserved against further trouble by dropping them in a can of kerosene. I used to advise carefully grinding them in the dirt to destroy them, but several men have informed me that a cup of kerosene sitting in some handy place is far more certain death. All the eattle should be carefully searched daily, until it is quite certain that no more can get on them. Tame cattle appreciate the act of relieving them, and will allow the ticks to be picked off anywhere. Trild catle should be confined in a chute. Light is necessary. Small ticks may be felt by smonthing the hand orer the hairs.

Small tickis are best killed, and seedticks kept from getting on, by kerolard mixtme put on with a brush and well rubbed in, so that it thoronghly greases them. For each gallon of kerosene nse one gallon of lard and one pound of sulphur flowers. A quart of pine tar may be added. Melt the lard, put in the sulphur, and bring the oil to the boiling point. Stir up the sulphur a few times. Take from the fire, allow to cool somewhat, and add the kerosene. When cool enough, stir to mix in the sulphur. Some say that cotton-seed oil and s11 phur are better. Examine the eattle the day after greasing, to see if the ticks are still kicking. Some may be found at this time which escaped the greasing. If the eattle are to be turned on tick infested pastures keep up the greasing and watching so long as any are left; which will he thronghont the season. Next season there will be none. If cattle are turned into clean pastures there will be no need of examinations after the first lot are killed, but none may be allowed to escape.

Mr. R. H. Ricks, of Rocky MLount, recommends the following mixtnre, which will also keep flies off: Fish oil, one gallon; kerosene, one quart; linseed oil, two quarts; pine tar, two quarts; carbolic acid, two tablespoonfuls; mix and apply with a broombrush or old shoebrush. 
Picking ticks and greasing requires but a short time of careful work each day, for all ordinary herds. It is best done by young people under supervision of a person of experience. Thoroughness saves much time and labor. Large herds may be handled much cheaper than is at first apparent by the same processes. During the last five years many herds have been entirely freed by these processes.

\section{TO AVOID TICKS.}

I)on't permit a ticky cow to come on your farm.

Don't drive your cattle where ticky cattle may have been.

If your cattle are ticky, clean them and put them on cultivated pasture lands.

If your cattle are ticky, and you have enough clean pasturage or forage that you can use, put them in a clean pen or pasture and leave them for three weeks, no longer. Take them out, and put them into another, and leave there three more. Then examine closely, and if entirely free put them in your large pasture. If not, put them into another pen for' a week or two, when they surely will be clean. Then change them. These changes are made before the young ticks can hatch ont, and they are consequently left in the pens to die out at their leisure.

If your cattle are ticky, and you have not the means of following this plan, pick the ticks, grease the cattle, and repeat the operation daily. You will succeed. It is easier than one thinks.

A good time to attack the tick problem is in the fall when the pastures, afforded by clearing off the crops, are available. The free range or fence-law country is in excellent shape to take advantage of such fields as all are under fence, and the cattle that come off the range may be cleansed and immediately put upon them.

If all the cattle of the free range are treated in this manner, the free range will disinfect itself by the opening of spring. All the cattle should be taken up by September. Try it. 


\section{TO PREVENT SEED TICKS.}

Seed ticks are the young of large ticks, and are just as they emerge from the egg-shell. They never get any larger, nor do they eat until they get on cattle. If they can not get upon cattle, they finally starve to death.

Keeping cattle from infected places for a year has disinfected these places. It is probable that removing cattle from an infected field as late as September 1st, will disinfect it by February. It is not probable that fields infected during summer are ever disinfected by the starvation process the same year.

Winter probably kills all the seed ticks, but does not kill the late laid eggs, which hatch on approach of warm weather. Still some of these may be killed. Some ticks live over on the cattle, and their eggs carry the stock for the year.

Fire kills seed ticks, but it is not advisable to use fire at all times, for it destroys leaves which should cover the ground in woods; and timber and much regetable matter, which should enrich the land.

Cultivation, by covering the ticks and starving them out, always disinfects. Pastures following grain or other crops are always free, until reinfected by the cattle.

Killing the large ticks prevents the seed ticks. All ticks hatch from eggs laid by large ticks.

\section{TICK FEVER AND TREATMENT.}

The disease known as splenic fever in cattle is essentially a blood disease. It is due to the attacks of parasites introduced into the blood by ticks, and their enormous increase. These parasites destroy the corpuscles (little bodies ) of the blood which carry the red coloring matter. The coloring substance of the blood is given off in the urine and makes it red. The death of the red corpuscles is accompanied by intense fever, and exceedingly great emaciation of the body. This is most apparent in animals which recover. Toward the end of the fever the skin, where it can be seen, gets very white, and little, pale 
blood runs from slight euts. The liver gets yellow. The splcen very large, and when eut looks like mulberry jam. The bladder usually contains red urine. The gall bladder is usually full of thick bile.

The disease begins about five days after the seed ticks get on the cattle, and is finished as a rule in less than fourteen days. The cattle usually die a day or two after the farmer notices that they are sick. The first indication can only be told by a thermometer; but farmers, (if not provided with one), can get some idea of prevailing fever a day or two before the animal shows other symptoms of illness, by feeling of the skin with the hand.

\section{Treatment.}

All treatment of tick fever is uncertain in its results, but by following the proposed course you will save as many of the animals as by any other.

The affected animals rarely have large ticks upon them. The ticks are usually no larger than wheat grains. All these should be greased and worked off. Other cattle should be greased and removed entirely from the infected pastures. The sick should be put into the coolest place on the farm, and in the shade at least. Green corn blades or other tender and green stuff should be put within their reach, and plenty of water. Give in three equal doses, a pound and a half of Glaubers salts. These salts should be dissolved in a quart of warm water, with a teaspoonful of ground ginger added for each dose. Give each eight hours apart. For smaller animals use proportionally smaller doses.

Keep watch of all the animals, and at the first sign of fever, give the physic. Feed all cattle in which the disease may be expected on the tenderest green feed available. If any recover, do not force them on to dry food or grain too fast, as they can not digest as much as they could before they were taken sick. Their appetite usually regnlates these matters. They will be a long time picking up their flesh again. If they live beyond the fourth or fifth day after they are seen to be sick, their chances of recovery are good. 


\title{
THE TOIVN-COW DISEASE.
}

\author{
By CoOper Curtice, Veterinarian.
}

Throughont the Soutli, especially in counties where stocklaw prerails, there has for a long time been a disease which kills the town cors. This disease has been varionsly ascribed to the pasturage, weeds, weather, water, dry food, and every other imaginable cause, but the right one.

All these cattle hare died, it is probable, from tick fever. Previous to the shutting ont of ticky cattle from Richmond, Virginia, the residents nsed to lose humdreds of cattle. All this was ascribed to the water, and malarial disease. Since then this loss has been totally stopped, and cattle are as healthy there as anywhere; but the reopening of traffic would again bring on the same plague.

The same thing is happening every year in this State. It is prodneed by these causes: Calves are raised all through the stocklaw region under conditions in which it is impossible for" them to become infected by the tick ferer. They may live for two or three years, or even more, withont becoming infected. But sooner or later they get moved around and driven on ticky roads or pastures, become infected, and either die or recover after a long and dangerous illness.

The infection of these cattle is brought about by other cattle which are permitted to spread ticks on the roads, or on the pastures.

Those people who think that it makes no difference if the cattle of others are ticky, are the losers. The uninformed owners of ticky cattle are responsible for the spread of disease quite as much so as if they were carrying a deadly poison in their pocket, which unknown to them, leaked ont to poison the herbage. The informed are criminally negligent. The rich man's, poor man's, and the dairyman's corv all die of the same carelessly-spread disease. The ticks are cowkillers, and respect no man's stock; the better the stock the more danger of the disease. 


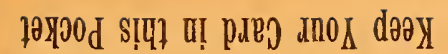

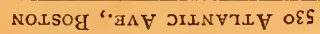

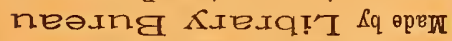

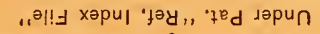

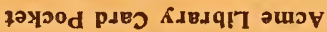


